\title{
Mass balance evolution of Martial Este Glacier, Tierra del Fuego (Argentina) for the period 1960-2099
}

\author{
M. Buttstädt ${ }^{1}$, M. Möller ${ }^{1}$, R. Iturraspe ${ }^{2}$, and C. Schneider ${ }^{1}$ \\ ${ }^{1}$ Department of Geography, RWTH Aachen University, 52056 Aachen, Germany \\ ${ }^{2}$ Water Resources Agency of Tierra del Fuego and University of Patagonia San Juan Bosco, Argentina
}

Received: 1 May 2009 - Revised: 2 September 2009 - Accepted: 3 September 2009 - Published: 14 December 2009

\begin{abstract}
The Martial Este Glacier in southern Tierra del Fuego was studied in order to estimate the surface mass balance from 1960 until 2099. For this reason a degree-day model was calibrated. Air temperature and precipitation data obtained from 3 weather stations as well as glaciological measurements were applied. The model was driven using a vertical air temperature gradient of $0.69 \mathrm{~K} / 100 \mathrm{~m}$, a degreeday factor for snow of $4.7 \mathrm{~mm}$ w.e. $\mathrm{K}^{-1} \mathrm{day}^{-1}$, a degree-day factor for ice of $9.4 \mathrm{~mm}$ w.e. $\mathrm{K}^{-1}$ day $^{-1}$ and a precipitation gradient of $22 \% / 100 \mathrm{~m}$. For the purpose of surface mass balance reconstruction for the time period 1960 until 2006 a winter vertical air temperature gradient of $0.57 \mathrm{~K} / 100 \mathrm{~m}$ and a summer vertical air temperature gradient of $0.71 \mathrm{~K} / 100 \mathrm{~m}$ were added as well as a digital terrain model. The key finding is an almost continuous negative mass balance of $-772 \mathrm{~mm}$ w.e. $\mathrm{a}^{-1}$ throughout this period. While the calculation of the mass balance for the period 1960-2006 is based on instrumental records, the mass balance for the years 2007 until 2099 was estimated based on the IPCC SRES A2-scenario. To accomplish this estimation, the dataset of the global climate model HadCM3 was statistically downscaled to fit local conditions at Martial Este Glacier. Subsequently, the downscaled air temperature and precipitation were applied to a volume-area scaling glacier change model. Findings reveal an enduring deglaciation resulting in a surface area reduction of nearly $93 \%$ until 2099. This implicates that the Martial Este Glacier might be melted off at the beginning of the 22nd century.
\end{abstract}

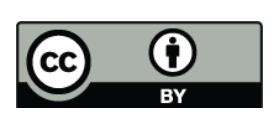

Correspondence to: M. Buttstädt (mareike.buttstaedt@geo.rwthaachen.de)

\section{Introduction}

Since glaciers affect morphologic, hydrologic and bioecologic developments of mountain areas they are a good indicator for climate change. Air temperature variations and precipitation perturbations lead to altered lengths of ablation and accumulation periods, which in turn cause modifications in glacier mass balance. Among others, glaciers in Patagonia register the strongest mass losses per unit area between 1961 and 2004 (IPCC, 2007). The melt water of the glaciers in the Cordón Martial mountain range - Martial Sur, Martial Central Oeste, Martial Central Este and in particular Martial Este $\left(68^{\circ} 24^{\prime} 11^{\prime \prime} \mathrm{W} 54^{\circ} 46^{\prime} 53^{\prime \prime} \mathrm{S}\right)$ - plays an important role for Ushuaia City as a provider for potable water supply. Glaciological research activities at the Martial Este Glacier date back to the 1980s. Strelin and Iturraspe (2007) investigated variations in glacier extent and applied a degree-day model for the years 2000 until 2004 (Iturraspe and Strelin, 2005). Strelin and Iturraspe (2002 and 2007) determined a considerable retreat of Martial Este Glacier since the terminus of the Little Ice Age by geomorphological analysis. Furthermore, they determined a positive air temperature trend for the last 30 years and ascertained a good correspondence between the area fluctuations of the Cordón Martial Glaciers and the 20th century annual air temperature and precipitation data of Ushuaia. Due to an extrapolation of this trend into the future, they infer that Martial Este Glacier will be the only glacier in the Cordón Martial mountain range that might still exist at the end of the current century. Holmlund and Fuenzalida (1995) contributed with their work to research activities in Chilean Tierra del Fuego by examining the behaviour of glaciers in the Cordillera Darwin. But still, long-term mass balance time series are rare in southernmost Patagonia. Apart from the work of Möller and Schneider (2008), no

Published by Copernicus Publications on behalf of the European Geosciences Union. 
continuous 20th century long-term mass balance time series have been reconstructed for any ice cap or glacier in Patagonia, nor has a simulation of future surface mass balance variations in response to global climate change been assessed.

The Martial Este Glacier is situated in Tierra del Fuego north of Ushuaia (southern Argentina) (Fig. 1). The influence of the Southern Hemisphere Westerlies, the vicinity of the Antarctic Peninsula and the almost homogeneous surrounding oceans determine the specific climate in southern Tierra del Fuego. With an area of around $0.088 \mathrm{~km}^{2}$ Martial Este Glacier is one of four cirque glaciers in the Cordón Martial mountain range. It extends in a southwest-northeast direction. The study area is located in the east of Cordillera Darwin and the mountains of Hoste Island. Thus, it is characterized by a moderate lee-side effect marked by lower values of precipitation, relative humidity and cloudiness than in the western mountain range (Strelin and Iturraspe, 2002). Furthermore, the west-east stretching mountain range shows a partially canalising effect of oceanic air masses and the current west-east passage of cyclonic systems determines a rain regime of low intensity and high frequency. This is reflected by the mean annual precipitation of about $500 \mathrm{~mm}$ (19611990 ) at the weather station Ushuaia (20 m a.s.l.). The annual air temperature in Ushuaia averages $+5.7^{\circ} \mathrm{C}$ (1961-1990) which causes a climate with mean air temperature around $0^{\circ} \mathrm{C}$ at Martial Este Glacier in 990 to $1200 \mathrm{~m}$ a.s.l.

The purpose of this study is to derive a continuous surface mass balance time series of Martial Este Glacier for the period 1960 until 2099 by means of degree-day modelling. The degree-day approach is an approved method to model ablation at the glacier surface (Hock, 2003). The method is based on the fact that incoming shortwave radiation and sensible heat flux are strongly correlated to air temperature and usually represent the largest energy sources for melting (Ohmura, 2001). The ongoing recession of the glaciated area is included in the model by applying a volume-area relation within the model structure (Bahr et al., 1997; Van de Wal and Wild, 2001). For this reason the area-volume change (AVC) model of Möller and Schneider (2009) was adopted. Besides modelling of glacier mass balance, the results may give an impetus for further considerations regarding prospective handling with potable water reserves.

\section{Data}

On the one hand, the calibration of the degree-day model is based on air temperature and precipitation data from 3 (automatic) weather stations ((A)WS) (Table 1). These datasets cover different partly overlapping time periods and provide daily air temperature and precipitation records for the period 1 August 1958 until 25 August 2007. From WS Ushuaia and WS CADIC daily air temperature and precipitation means collected by a thermometer, a rain gauge and a snow collector according to WMO standards were available. Hourly air temperature and precipitation data at $990 \mathrm{~m}$ a.s.l., close to the glacier front were obtained by a datalogger and a rain gauge connected to a tipping bucket with snow collector containing antifreeze. In addition, an AWS was installed in October 2005. Air temperature accuracy is $\pm 0.2^{\circ} \mathrm{C}$ for all 3 stations. The rain gauge at AWS Martial Este collects suitable data in summer, also for snow precipitation, but it underestimates values in winter, especially in case of heavy snowfall and concurrently strong winds. By means of considering the altitudinal variation of precipitation based on data from WS Ushuaia (Iturraspe et al., 2007), the error estimating precipitation at the glacier is about $\pm 15 \%$.

On the other hand, glaciological data, based on direct measurements at intervals of 10 days between 1 December 2005 and 28 February 2006, are used. These measurements afford a reasonable data basis for the calibration. Ablation and accumulation respectively were measured at 10 ablation stakes equally distributed over the glacier area (Fig. 1). These measurements were complemented by density samples in snow pits at $20 \mathrm{~cm}$ intervals using a sampler with a diameter of $5.7 \mathrm{~cm}$. Errors in mass balances are estimated at $\pm 50 \mathrm{~mm}$ w.e. (Strelin and Iturraspe, 2007). By means of the known volume a mean density of $470 \mathrm{~kg} / \mathrm{m}^{3}$ for snow could be assessed. The density of ice was assumed to be constant at a value of $917 \mathrm{~kg} / \mathrm{m}^{3}$ (Paterson, 1994).

Surface mass balance reconstruction from 1960 until 2007 is based on a subset of air temperature and precipitation records from WS Ushuaia and WS CADIC. Data of WS CADIC were used in case of data gaps of WS Ushuaia. In addition, a digital terrain model representing the glacier surface elevations and extensions in 2002 was incorporated. By comprising a topographical map (1:100 000) of Ushuaia and a topographical map of Martial Este Glacier published in WGMS (2005) the digital terrain model was created by employing ArcGIS software. As interpolation technique the method of triangulated irregular network was applied.

The estimation of 21st century surface mass balance time series contains monthly mean $2 \mathrm{~m}$ surface air temperature and monthly precipitation sum grids of the Third UK Met Office Hadley Centre Coupled Ocean-Atmosphere global climate model (HadCM3) (Lowe, 2005). Representing the IPCC SRES (Intergovernmental Panel on Climate Change Special Report on Emissions Scenarios) scenario A2 the datasets could be regarded as worst case climate forcing for glacier change (IPCC, 2007). Data of the nearest HadCM3 grid point $\left(55.0^{\circ} \mathrm{S}, 67.5^{\circ} \mathrm{W}\right)$ were statistically downscaled by the implementation of the "local scaling" method based on a comparison with data of the WS Ushuaia for the period 2000-2006. By means of local scaling the synopticscale mean seasonal cycle can be adjusted to the local-scale cycle. By calculating the mean seasonal cycles of the detrended datasets and further data correction according to the biases between the monthly values of the seasonal cycles of the synoptic-scale air temperature and precipitation data and the respective monthly values of the seasonal cycles of the 

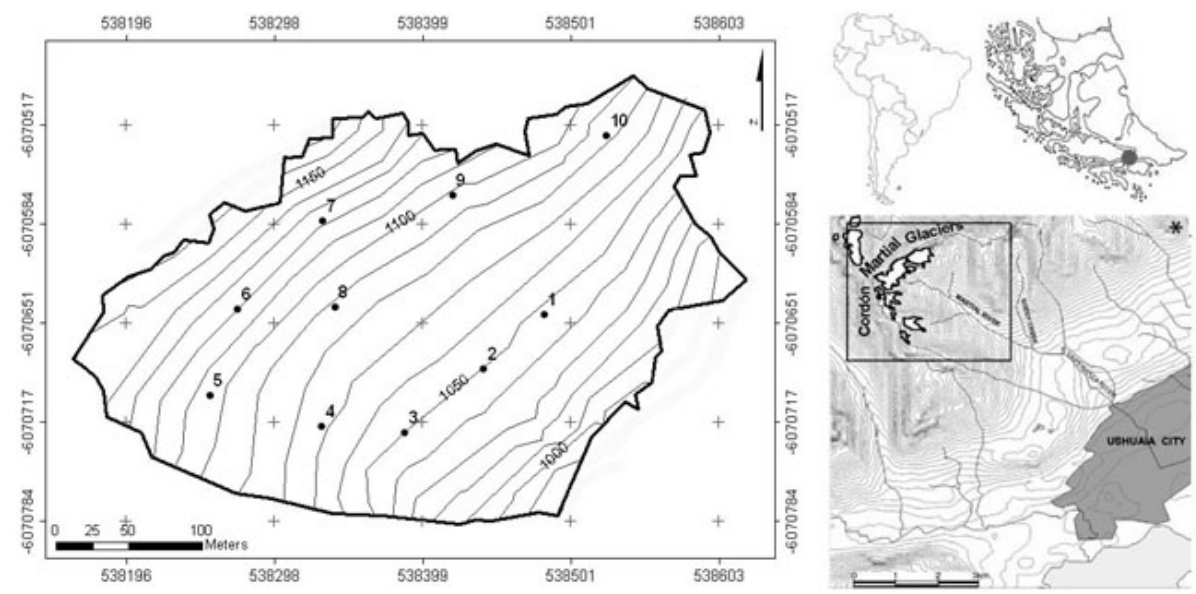

Fig. 1. Glacier location and distribution of ablation stakes over Martial Este Glacier (April 2005). * Strelin and Iturraspe (2007).

Table 1. Overview of the weather stations which provided the necessary air temperature and precipitation data records for this study. (A)WS=(automatic) weather station.

\begin{tabular}{|c|c|c|c|c|}
\hline Station & Type & lat./long. & ma.s.1 & $\begin{array}{l}\text { Time period of } \\
\text { data collection }\end{array}$ \\
\hline Ushuaia & WS & $\begin{array}{r}54^{\circ} 50^{\prime} 28^{\prime \prime} \mathrm{S} \\
68^{\circ} 17^{\prime} 51^{\prime \prime} \mathrm{W}\end{array}$ & 20 & $\begin{array}{l}\text { since } 1957 \\
\text { (partly since 1878) }\end{array}$ \\
\hline CADIC & WS & $\begin{array}{r}54^{\circ} 49^{\prime} 54^{\prime \prime} \mathrm{S} \\
68^{\circ} 19^{\prime} 24^{\prime \prime} \mathrm{W}\end{array}$ & 24 & since 1985 \\
\hline Martial Este & AWS & $\begin{array}{r}54^{\circ} 46^{\prime} 54^{\prime \prime} \mathrm{S} \\
68^{\circ} 23^{\prime} 58^{\prime \prime} \mathrm{W}\end{array}$ & 990 & $\begin{array}{l}\text { since } 2000 \\
\text { (partly since 2005) }\end{array}$ \\
\hline
\end{tabular}

measurements at AWS, the data were "locally scaled". This method is described in detail in Salathé (2005) and Widmann et al. (2003).

\section{Method}

\subsection{Calibration of the degree-day model}

A degree-day model is based on the correlation between air temperature $\left(T,{ }^{\circ} \mathrm{C}\right)$ and melting. According to Braithwaite (1995) it can be described as:

$A=\sum_{i=1}^{i=n} \mathrm{DDF} \cdot c T_{i} \quad \begin{array}{ll}c=1 \text { for } T_{i}>0^{\circ} \mathrm{C} \\ c=0 \text { for } T_{i} \leq 0^{\circ} \mathrm{C}\end{array}$

The degree-day factor (DDF) describes the relation between ablation ( $A$, mmw.e.) and air temperature (Zhang et al., 2006) and quantifies the melting glacier mass in mm w.e. per degree-day. DDFs show a high degree of stability with time and within different climatic regimes (Braithwaite and Olesen, 1989). It is assumed that the determined relations from past or present situations will not change significantly in the future.

Due to a higher albedo of snow than of ice the $\mathrm{DDF}_{\text {snow }}$ is set to $1 / 2 \cdot \mathrm{DDF}_{\text {ice }}$ (Braithwaite, 1995). Positive degreedays (PDDs) are any days with a mean daily air temperature above the melting point. According to Braithwaite (1984) they can be ascertained by the summation of all positive air temperatures.

In contrast to mean annual air temperatures, PDDs are strongly linked to ablation (Benn and Evans, 1998). To determine the specific mass balance, the accumulation $(S$, $\mathrm{mm}$ w.e.) must be added to the model in terms of precipitation $(P, \mathrm{~mm})$ as well.

$S=\sum_{i}^{n} P_{i}$ for $T_{i}<0^{\circ} \mathrm{C}$

$S=0 \quad$ for $T_{i}>0^{\circ} \mathrm{C}$

In addition, an air temperature threshold between 0 and $2^{\circ} \mathrm{C}$ was defined due to the fact that at air temperatures slightly above the melting point precipitation can be either solid or liquid. Therefore, the amount of solid precipitation $\left(P_{S}\right)$ was scaled between $100 \%\left(0^{\circ} \mathrm{C}\right)$ and $0 \%\left(2^{\circ} \mathrm{C}\right)$ according to Möller et al. (2007):

$P_{s}=0,5\{-\tanh [(T-1) \cdot 3]+1\}$

Because of deficient measurements of precipitation by the rain gauge at AWS Martial Este - mainly caused by wind drift - the precipitation gradient was only available as an estimated value of about $20 \% / 100 \mathrm{~m}$. This altitudinal variation of precipitation studied by Iturraspe et al. (2007) is based on data from rain-snow collectors at different levels and snow accumulation measurements on the glacier surface. 
The vertical air temperature gradient is $0.69 \mathrm{~K} / 100 \mathrm{~m}$. This calculation comprises air temperature data of the measuring period (21 December 2005 until 22 February 2006) from AWS Martial Este and WS Ushuaia/WS CADIC. In order to determine the DDFs the relationship between the amount of snow and ice melting and PDDs is illustrated (Fig. 2). Any PDD contributes to melt so that the regression line is forced through 0 . The regression line shows a DDF of almost $5.3 \mathrm{mmw}$.e. $\mathrm{K}^{-1}$ day $^{-1}$ at a coefficient of determination of approximately $94 \%$ which implicates a satisfactory model performance. This DDF includes snow melt as well as ice melt. The exact contributory amount of snow and ice respectively is unclear while it is assured that the melting of snow accounts for 80 to $90 \%$ of the whole ablation. Based on this fact, the $\mathrm{DDF}_{\text {snow }}$ was set to a limit of $4.4-4.7 \mathrm{~mm}$ w.e. $\mathrm{K}^{-1}$ day $^{-1}$ and the $\mathrm{DDF}_{\text {ice }}$ to 8.8-9.4 mm w.e. $\mathrm{K}^{-1}$ day $^{-1}$ (which is twice the amount of $\left.\mathrm{DDF}_{\text {snow }}\right)$. Otherwise the deviation from the conjoint regression line would be too pronounced. Moreover, each beforehand appointed DDF was combined with a precipitation gradient between 19 and $22 \% / 100 \mathrm{~m}$.

In each case the sum of absolute melt in mmw.e. during the whole period (21 December 2005 until 22 February 2006) and over all ablation stakes was calculated as well as the difference between measured and modelled values. Best fit was achieved for a $\mathrm{DDF}_{\text {snow }}=4.7 \mathrm{~mm}$ w.e. $\mathrm{K}^{-1}$ day $^{-1}$ and a $\mathrm{DDF}_{\text {ice }}=9.4 \mathrm{~mm}$ w.e. $\mathrm{K}^{-1}$ day $^{-1}$ with modelled ablation accounting for $94 \%$ of the variance of the measured amounts (Fig. 3). Cumulative measured and modelled melt are equivalent during the measuring period (21 December 2005 until 22 February 2006). As this calibration result reveals a good model performance the degree-day model was adapted to reconstruct the mass balance since 1960 and to model the mass balance until 2099. To achieve results as precise as possible the air temperature lapse rate was split into a winter air temperature gradient of $0.57 \mathrm{~K} / 100 \mathrm{~m}$ and a summer air temperature gradient of $0.71 \mathrm{~K} / 100 \mathrm{~m}$. These gradients are the mean calculated values during the summer (April-September) and winter months (October-March) in the period between 1 January 1999 and 31 December 2006 at WS Ushuaia and WS CADIC.

\subsection{Mass balance sensitivity}

To examine the dependency of the mass balance on air temperature and precipitation a simulation of potential mass balance changes due to air temperature changes as well as precipitation perturbations was carried out. Presuming $+10 \%$ and $-10 \%$ precipitation offset, as well as $+1 \mathrm{~K}$ and $-1 \mathrm{~K}$ air temperature variation the corresponding mass balances with regard to the reference period were built (Table 2). As input data for the reference period the mean mass balance in the period 2000 until 2006 was used.

To determine the seasonal sensitivity of Martial Este Glacier to climate perturbations, a method after Oerlemans

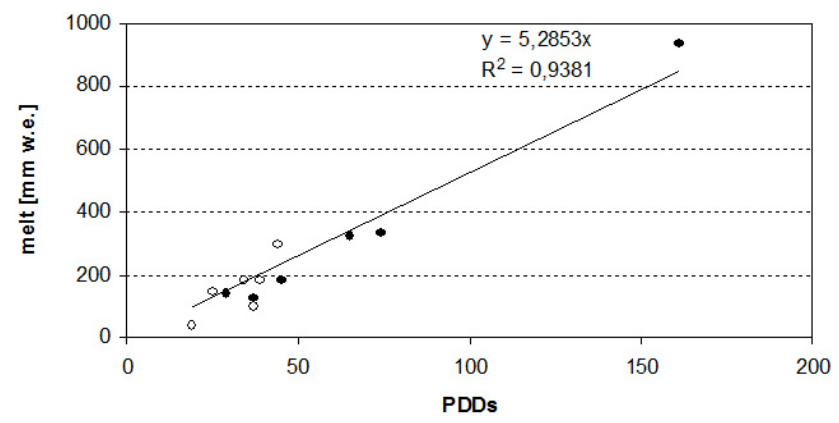

Fig. 2. Determination of the DDF using the correlation between snow/ice melt and PDDs. The white dots are measured values during the summer months 2005/06. Data of the summer months 2004/05 and March 2006 (black dots) are provided by Iturraspe and Strelin (2005).

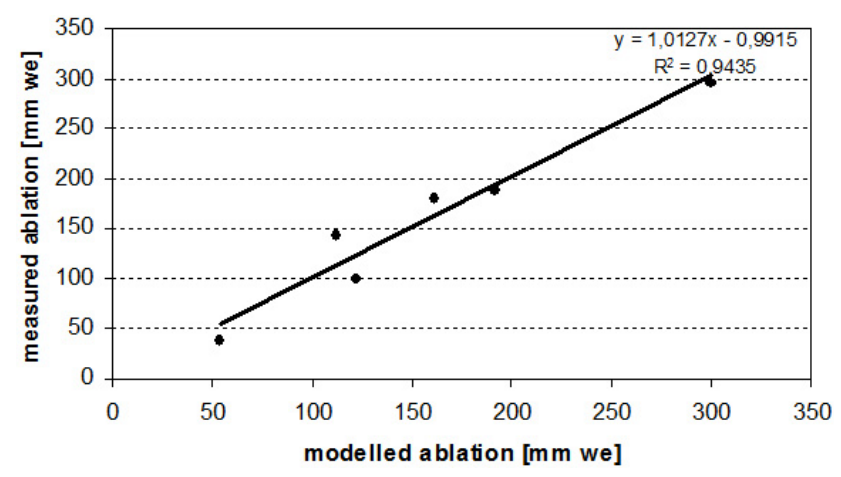

Fig. 3. Comparison between measured and modelled ablation at Martial Este Glacier for the period 21 December 2005 until 22 February 2006.

and Reichert (2000) was used. In this context, the coefficients $C_{T, k}$ and $C_{P, k}$ for each month $(k)$ describe the mean change of surface mass balance relative to the reference year due to changes in air temperature and precipitation according to

$C_{T, k}=\frac{\partial B}{\partial T_{k}} \approx \frac{B_{k, T+1}-B_{k, T-1}}{2} \quad$ for $k=1, \ldots, 12$

$\begin{aligned} C_{P, k}= & \frac{\partial B}{\partial\left(\frac{P_{k}}{P_{r e f, k}}\right)} \approx 10 \cdot \frac{B_{k, P=1,1}-B_{k, P=0,9}}{2} \\ & \text { for } k=1, \ldots, 12 .\end{aligned}$

\subsection{Area and volume change model}

The continuous oncoming area change of Martial Este Glacier until 2099 is estimated using the AVC model described by Möller and Schneider (2009). It is based on the relationship between glacier volume and surface area presented by Bahr et al. (1997). They show that the volume $\left(V, \mathrm{~m}^{3}\right)$ 


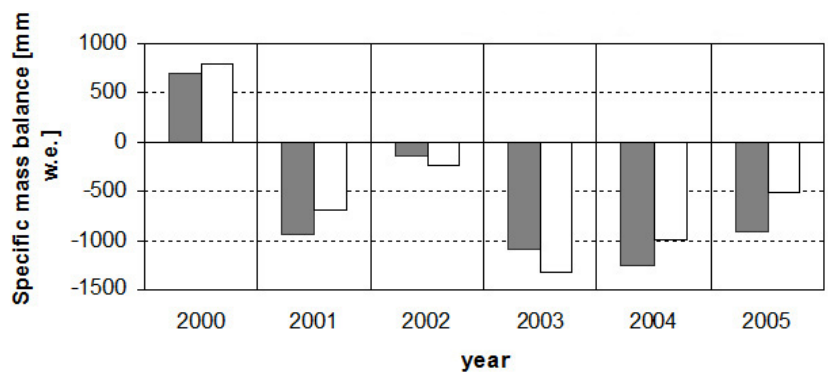

Fig. 4. Comparison of calculated mass balances. The grey (modelled, this study) and white (measured, Strelin and Iturraspe (2007), 2000-2003; WGMS (2005), 2004-2005) columns show the mass balance of Martial Este Glacier.

can be written as a function of the characteristic surface area $\left(A, \mathrm{~m}^{2}\right)$ of any glacier in steady state with $\gamma$ depending on glacier type:

$V=A^{\gamma}$

In case of glaciers, which are not in steady state a scaling coefficient $c\left(\mathrm{~m}^{3-2 \gamma}\right)$ must be added to Eq. (6) as follows (Van de Wal and Wild, 2001; Radić and Hock, 2006):

$V=c \cdot A^{\gamma}$

Bahr et al. (1997) obtained a fixed $\gamma$ of 1.375 for valley glaciers and 1.25 for ice caps. For the specific calibration for Martial Este Glacier, which forms a typical cirque glacier $\gamma$ was set to 1.375 as it was the closer choice.

Following Radic and Hock (2006) the scaling coefficient $\mathrm{c}$ was calculated to 0.454 from given glacier area $\left(0.088 \mathrm{~km}^{2}\right)$ and volume $\left(0.0029 \pm 0.0005 \mathrm{~km}^{3}\right)$ information in 1998 (Strelin and Iturraspe, 2007). The volume-area relation of Martial Este Glacier thus reads:

$V=0.454 \cdot A^{1.375}$

During the AVC model runs surface mass balance is calculated using a modified version of the degree-day model employed for the assessment of the climate sensitivity of Martial Este Glacier. Due to the fact that data of global climate models are only available on a monthly basis, the statistical distribution of intra-month air temperature variations has to be taken into account. This is achieved by including the probability density function of mean daily air temperature at Martial Este Glacier for the calculation of PDDs used as input for the degree-day model (e.g. Braithwaite, 1984). For more details on that procedure see Möller and Schneider (2009).

Mean annual surface mass balances were recalculated to ice volume changes at the end of each year. The associated area change was then calculated using the specific volumearea relation of Martial Este Glacier (Eq. 8) according to

$A_{y+1}=\left(\frac{V_{y}+\Delta V_{y}}{c}\right)^{\frac{1}{\gamma}}$.
Table 2. Glacier mass balance depending on precipitation and/or air temperature changes. Values stand for mass balance variations in mm w.e. compared to the reference period (2000 until 2006). Values in brackets show the absolute mass loss.

\begin{tabular}{rrrr}
\hline $\mathrm{N} / \mathrm{T}$ & $-1 \mathrm{~K}$ & $0 \mathrm{~K}$ & $+1 \mathrm{~K}$ \\
\hline$+10 \%$ & $+1110(+577)$ & $+219(-314)$ & $-1466(-1999)$ \\
$0 \%$ & $+961(+428)$ & $0(-533)$ & $-1702(-2235)$ \\
$-10 \%$ & $+794(+261)$ & $-226(-759)$ & $-1923(-2456)$ \\
\hline
\end{tabular}

Glacier area is adjusted by cutting off digital terrain model grid cells in order of increasing glacier altitude starting at the lowest ice margin (Möller and Schneider, 2009).

\section{Results and discussion}

Together with air temperature and precipitation data and a digital terrain model the findings of the calibration were used to determine the specific mass balance of Martial Este Glacier. Results reveal an almost continuous negative mass balance, which has strongly contributed to a reduction of the glacier surface area in the last 30 years. The negative mass balance in the period 1960 until 2006 averages $-772 \mathrm{~mm}$ w.e. $\mathrm{a}^{-1}$, whereas the mean annual loss in the period 2000 until 2006 is about $-533 \mathrm{~mm}$ w.e. $\mathrm{a}^{-1}$. The mean equilibrium line altitude was $1130 \mathrm{~m}$ a.s.l. These findings conform to the results of previous works by Strelin and Iturraspe (2002 and 2007). The results in this study affirm that the high melting rate during the whole period was mainly caused by remarkable air temperature increase at the end of the 1980s and the beginning of the 1990s as well as an extraordinary decrease in precipitation in 1983. By comparing the modelled mass balance for the period 2000 until 2005 with the results of the mass balance studies at Martial Este Glacier by Strelin and Iturraspe (2007) as well as provided mass balance data by WGMS (2005) a good accordance can be stated (Fig. 4). The application of the degree-day model is facilitated by the requirement of air temperature and precipitation data only. Hence, in comparison to other approaches, it holds some valuable advantages such as the possibility of extrapolating air temperature easily over the whole glacier area (Jóhannesson et al., 1995) and to the future. However, it must be stated that the applicability of a degree-day model is limited. Instead of river discharge measurements normally only 2 annual measurements are integrated into the model calibration. Based on the resulting coarse time resolution compared to traditional hydrological degree-day snow melt models, the mass balance model is suitable for estimating the variation of run-off with elevation but less suitable for analysing time-dependent melting. A combination of mass-balance and run-off models might lead to improved results (Jóhannesson et al., 1995). Furthermore, it should be 


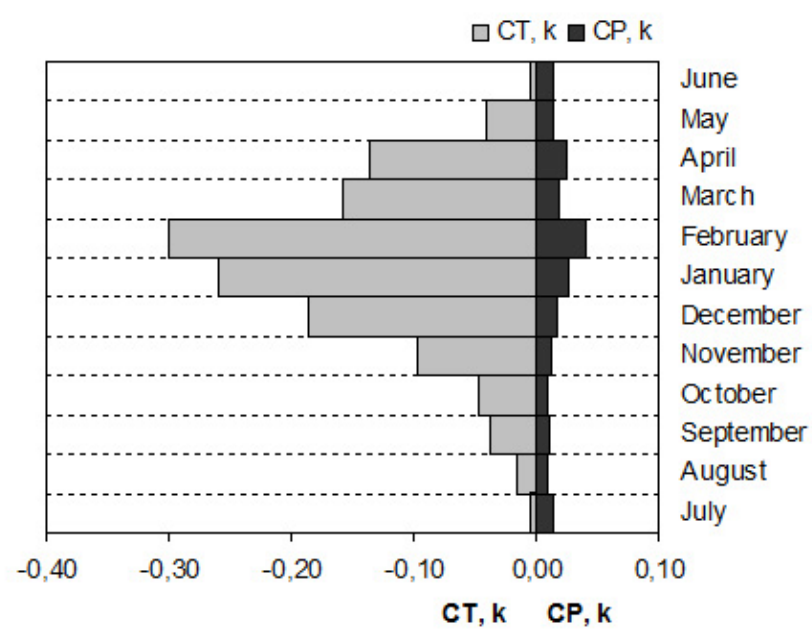

Fig. 5. Seasonal sensitivity characteristic for Martial Este Glacier, calculated with a degree-day model. The sensitivity of the specific balance for monthly perturbations is denoted by $C_{T, k}$ and $C_{P, k}$. The indices refer to air temperature $(T)$, precipitation $(P)$ and the month $(k=1, \ldots, 12)$. The precipitation sensitivity coefficient was divided by a factor of 10 .

mentioned that the application of a degree-day model is only suitable for glaciers at which wind drift does not play a major role. Nevertheless, after Bergström et al. (1992) energy balance models do not seem to perform much better than a degree-day model, although this simple approach has the limitation that physical processes are not represented directly but only represented by coarse approximation. Spatially defined to the catchment scale the degree-day method provides adequate results (Hock, 2003).

The calculation concerning the dependency of the mass balance on air temperature and precipitation shows - compared to 37 studied glaciers worldwide by Braithwaite and Zhang (1999) - an above-average air temperature sensitivity (Fig. 5). In contrast to that, precipitation changes are of almost no significance.

The downscaled climate data time series show almost no precipitation trend and slightly increasing air temperature (Fig. 6). However, it must be kept in mind that neither the original global climate model runs itself, nor the downscaled Hadley Centre global climate model data which shows only an explained variance of $41 \%$ compared to measured precipitation in the period 2000-2007 (Table 3) are able to estimate precipitation precisely. To ensure that the downscaled climate data is suitable for surface mass balance modeling the HadCM3 time series was compared with the measured air temperature and precipitation record from WS Ushuaia. Correlations and explained variances were calculated and tested for significance. The reduction of the significance levels due to auto-correlation was taken into account. The results indicate a very good performance of the downscaling method
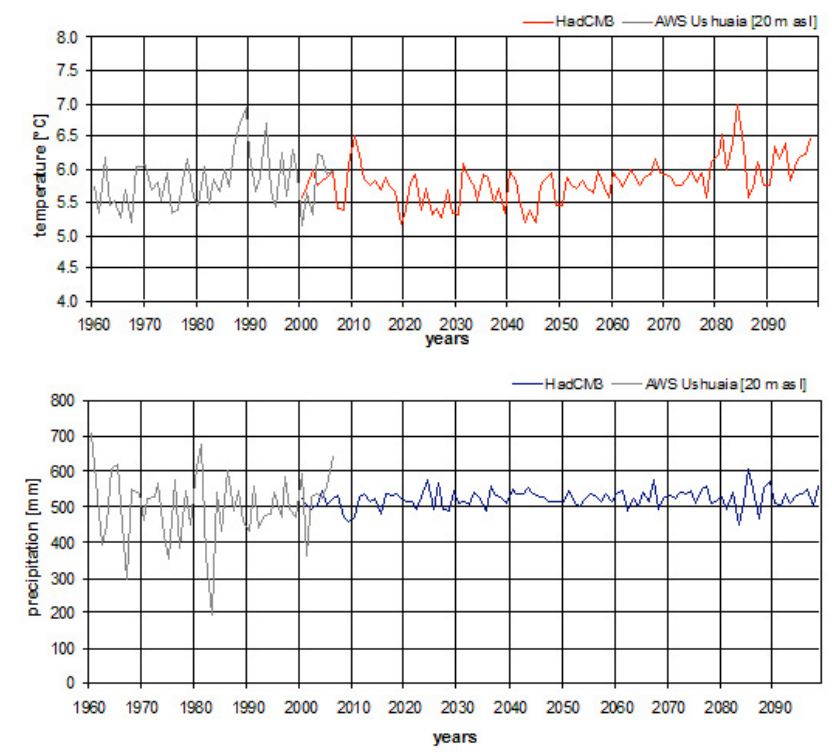

Fig. 6. Measured and downscaled climate data time series for the period 1960-2099.

Table 3. Error estimation regarding the downscaling of the HadCM3 data.

\begin{tabular}{lrr}
\hline & Temperature & Precipitation \\
\hline$N$ & 72 & 72 \\
$R^{2}$ & 0.95 & 0.41 \\
Significance level incl. & $99.9 \%$ & $99.9 \%$ \\
auto- correlation & & \\
\hline
\end{tabular}

as it is expressed by a high (95\%) explained variance for the downscaled air temperature time series and a moderate explained variance of $41 \%$ for precipitation. Due to a high significance of the correlation at the $99.5 \%$ level all climate data used are assumed to be applicable for the surface mass balance time series modelling.

To obtain uncertainties and error ranges of the surface mass balance time series based on the HadCM3 dataset it was compared to a reference surface mass balance time series. The latter was obtained by driving the surface mass balance model with the daily records of WS Ushuaia for the period 2000-2006. Results prove a good performance of the modelling procedure as revealed by an explained variance of $91 \%$ (Table 4). The associated error range is induced by possible inaccuracies of the DDF calibration. It is assessed on an annual basis by additional model runs with $\mathrm{DDF}_{\text {ice }} \pm 1.0 \mathrm{~mm}$ w.e. $\mathrm{K}^{-1}$ day $^{-1}$ and $\mathrm{DDF}_{\text {snow }} \pm 0.5 \mathrm{~mm}$ w.e. $\mathrm{K}^{-1}$ day $^{-1}$ as suggested by Möller and Schneider (2008). 
Table 4. Error estimation regarding the HadCM3 data based surface mass balance time series.

\begin{tabular}{lr}
\hline$N$ & 72 \\
$R^{2}$ & 0.91 \\
Annual rms error (m w.e.) & 0.47 \\
Significance level incl. auto-correlation & $99.9 \%$ \\
Mean annual offset (m w.e.) & +0.34 \\
\hline
\end{tabular}

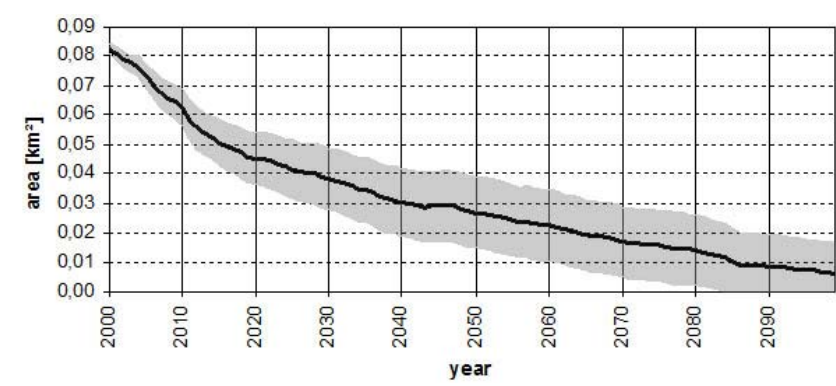

Fig. 7. Evolution of the surface area of Martial Este Glacier 20002099.

The AVC model reveals a reduction of the surface area of Martial Este Glacier down to $0.006 \pm 0.01 \mathrm{~km}^{2}$ by 2099 assuming the IPCC SRES scenario A2 as climate forcing. This equals a recession of the glacier to $7 \%$ of its glacier area in year 2000 (Fig. 7). The given uncertainty range mirrors the sensitivity of the AVC model to possible DDF inaccuracies and the uncertainty in the volume-area scaling power law itself. The former is assessed by additional model runs with altered DDFs as likewise done in case of the surface mass balance time series error analysis. The latter, however, accounts for the \pm 0.125 uncertainty of the scaling exponent of the volume-area relation (Van de Wal and Wild, 2001).

\section{Summary}

The application of a calibrated degree-day model for mass balance reconstruction since 1960 shows a strong mass loss until 2006. The continuation of this trend into the future as it was figured out by factoring downscaled precipitation and air temperature time series into the AVC model - is a corollary of increasing air temperature and almost unchanging precipitation. The surface area of Martial Este Glacier, which amounted about $0.13 \mathrm{~km}^{2}$ in 1960 comprises a remaining area of barely $0.006 \mathrm{~km}^{2}$ at the end of this century by means of a continuous negative mass balance until 2099 (Fig. 8). This implies that Martial Este Glacier might be melted off at the beginning of the 22nd century. Comparing air temperature variations of $\pm 1 \mathrm{~K}$ and precipitation changes of $\pm 10 \%$ it is shown that the sensitivity of the glacier on air temperature perturbations is much more pronounced Other

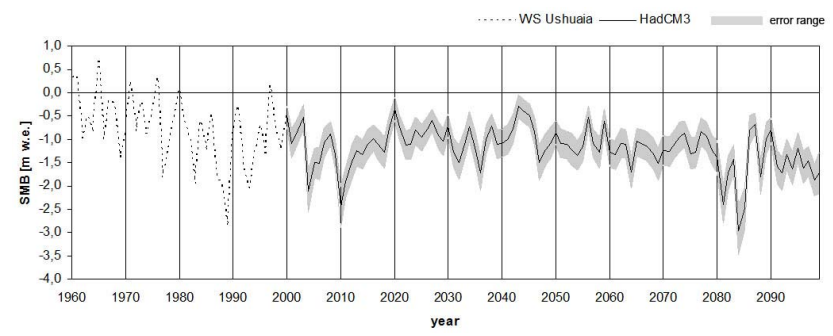

Fig. 8. Surface mass balance evolution of Martial Este Glacier 1960-2099.

glaciers of the Cordón Martial were not modelled but they show a more critical condition than Martial Este Glacier because of their exposition and actual size. At present the Martial Sur ice body ( $750 \mathrm{~m}$ a.s.l.), which is the southernmost glacier in the Cordón Martial and the most exposed one to the sun is close to disappear. Considering the contribution of the glacier to the runoff and the relevance of the glaciers for the landscape this trend might cause negative impacts in the area around the Martial Este Glacier. Since the population of Ushuaia obtains its potable water partly from the glacier melt a future challenge will be to find supplementary potable water sources in the context of a local strategy for adaptation to climate change.

Acknowledgements. This study was carried out in collaboration with the GEF-UNEP project "Glaciological Studies for the Planning of Water Uses in Climate Change Scenarios".

Edited by: P. Fabian

Reviewed by: three anonymous referees

\section{References}

Bahr, D. B., Meier, M. F., and Peckham, S. D.: The physical basis of glacier volume-area scaling. J. Geophys. Res., 102(B9), 2035520362, 1997.

Benn, D. I. and Evans, D. J. A.: Glaciers and glaciation, Arnold, London, 1998.

Bergström, S., Bøggild, C. E., Einarsson, K., Gjessing, Y., Saelthun, N. R., Thomsen, T., Vehviläinen, B., and Sand, K.: Snow modelling, water resources, climate change, edited by: Sand, K., NHL Report, Trondheim, 1992.

Braithwaite, R. J.: Calculation of degree-days for glacier-climate research, Zeitschrift für Gletscherkunde und Glazialgeologie, 20, 1-8, 1984.

Braithwaite, R. J.: Positive degree-day factors for ablation on the Greenland ice sheet studied by energy-balance modelling, J. Glaciol., 41(137), 153-160, 1995.

Braithwaite, R. J. and Olesen, O. B.: Calculation of glacier ablation from air temperature, edited by: Oerlemans, J., Glacier fluctuations and climate change, Dordrecht, 1989.

Braithwaite, R. J. and Zhang, Y.: Modelling changes in glacier mass balance that may occur as a result of climate changes, Geogr. Ann., 81A(4), 489-495, 1999. 
Hock, R.: Temperature index melt modelling in mountain areas, J. Hydrol., 282(1-4), 104-115, 2003.

Holmlund, P. and Fuenzalida, H.: Anomalous glacier responses to 20th century climatic changes in Darwin Cordillera, southern Chile, J. Glaciol., 41(139), 465-473, 1995.

IPCC: Climate Change 2007: The Physical Science Basis. Contribution of Working Group I to the Fourth Assessment Report of the Intergovernmental Panel on Climate Change, edited by: Solomon, S., Qin, D., Manning, M., Chen, Z., Marquis, M., Averyt, K. B., Tignor, M., and H. L. Miller, Cambridge, UK and New York, 2007.

Iturraspe, R. and Strelin, J.: Resultados de estudios glaciologicos en el Glaciar Martial, Tierra del Fuego, Anales del XX Congreso Nacional del Agua, 293-302, Published on CD, 2005.

Iturraspe, R., Urciuolo, A., Guerrero, V., Gaviño, M., Collado, L., Sarandón, R., and Burns, S.: Report on basin response for Argentina (D18), Epic Force Project Deliverables, Newcastle Univ., online available at: http://www.ceg.ncl.ac.uk/epicforce/ assets/D18.pdf, 2007.

Jóhannesson, T., Sigurdsson, O., Laumann, T., and Kennett, M.: Degree-day glacier mass-balance modelling with applications to glaciers in Iceland, Norway and Greenland, J. Glaciol., 41, 345358,1995 .

Lowe, J. A.: IPCC DDC AR4 UKMO-HadCM3 SRESA2 run1. CERA-DB "UKMO_HadCM3_SRESA2_1", online available at: http://cera-www.dkrz.de/WDCC/ui/Compact.jsp?acronym= UKMO_HadCM3_SRESA2_1, 2005.

Möller, M., Schneider, C., and Kilian, R.: Glacier change and climate forcing in recent decades at Gran Campo Nevado, southernmost Patagonia, Ann. Glaciol., 46, 136-144, 2007.

Möller, M. and Schneider, C.: Calibration of glacier volume-area relations from surface extent fluctuations and its application to future glacier change, J. Glaciol., revised, 2009.

Möller, M. and Schneider, C.: Climate sensitivity and mass-balance evolution of Gran Campo Nevado ice cap, southwest Patagonia, Ann. Glaciol., 48, 32-42, 2008.
Oerlemans, J. and Reichert, R. K.: Relating glacier mass balance to meteorological data by using a seasonal sensitivity characteristic, J. Glaciol., 46(152), 1-6, 2000.

Ohmura, A.: Physical basis for the temperature-based melt-index method. J. Appl. Meteorol., 40(4), 753-761, 2001.

Paterson, W. S. B.: The physics of glaciers, Reed educational and Professional Publishing Ltd., Oxford, 1994.

Radić, V. and Hock, R.: Modelling future glacier mass balance and volume canges using ERA-40 reanalysis and climate models A sensitivity study at Storglaciären, Sweden, J. Geophys. Res., 111, F03003, doi:10.1029/2005JF000440, 2006.

Salathé Jr., E. P.: Downscaling simulations of future global climate with application to hydrologic modelling, Int. J. Climatol., 25(4), 419-436, 2005.

Strelin, J. and Iturraspe, R.: La cuenca glacio-nival "Martial-Buena Esperanza". Actas "High Summit Conference 2002", Mendoza, 2002.

Strelin, J. and Iturraspe, R.: Recent evolution and mass balance of Cordón Martial glaciers, Cordillera Fueguina Oriental, Global Planet. Change, 59(1-4), 17-26, 2007.

Van de Wal, R. S. W. and Wild, M.: Modelling the response of glaciers to climate change by applying volume-area scaling in combination with a high resolution GCM, Clim. Dynam., 18(3/4), 359-366, 2001.

Widmann, M., Bretherton, C. S., and Salathé Jr., E. P.: Statistical precipitation downscaling over the northwestern United States using numerically simulated precipitation as a predictor, J. Climate, 16(5), 799-816, 2003.

WGMS (World Glacier Monitoring Service) (Eds.): Glacier mass balance bulletin No. 8, online available at: http://www.geo.unizh. $\mathrm{ch} / \mathrm{wgms} / \mathrm{mbb} / \mathrm{mbb} 9 / \mathrm{mbb} 9 . \mathrm{pdf}, 2005$.

Zhang, Y., Liu, S., and Ding, Y.: Observed degree-day factors and their spatial variation on glaciers in western China, Ann. Glaciol. 43, 301-306, 2006. 